\title{
Analyzing Writing Difficulties in The Beginning Writing of Second Grade Elementary School Students
}

\author{
IDA FARIDA1 DAYU RETNO PUSPITA² SEPTY NURFADHILLAH ${ }^{3}$ \\ Program Studi Pendidikan Guru Sekolah Dasar, Universitas Muhammadiyah Tangerang, Indonesia. \\ Email: dafafarida787@gmail.com ${ }^{1}$, dayuretnopuspita@gmail.com 2, \\ nurfadhillahsepty@gmail.com³
}

Article Received: 24 October 2019

Published Article: 30 April 2020

DOI: https://doi.org/10.29313/ga:jpaud.v3i2.5272

\begin{abstract}
This study aims to analyze difficulties and its causing factors from the beginning writing of second-grade students in one of the elementary schools in Tangerang, Indonesia. This research used the descriptive qualitative method. The data collected from the research results were described in the form of words. The results of this study were found in 28 students' writings that have been analyzed; as many as $75 \%$ of students have been completed in learning to start writing, and $25 \%$ of students have not finished writing in the beginning due to factors such as difficulties in fine motor skills, difficulty in perception of visualmotor coordination and visual memory difficulties. Students' difficulties were assessed from the aspect of beginning writing, namely: students' difficulty in the formation of formations, neatness of writing, spaces, form accuracy, proportions, and quality of writing lines.
\end{abstract}

Keywords: Learning Difficulties; Writing; Writing Beginning.

\begin{abstract}
Abstrak
Penelitian ini bertujuan untuk mengetahui kesulitan siswa dalam menulis permulaan dan faktor penyebab kesulitan menulis permulaan pada siswa kelas 2 di salah satu Sekolah Dasar di Tangerang. Metode yang digunakan dalam penelitian ini adalah metode kualitatif deskriptif, yaitu mengkaji dan menganalisis data secara objektif sesuai dengan data yang ditemukan dilapangan. Kemudian data yang terkumpul dari hasil penelitian di deskripsikan dalam bentuk kata-kata. Hasil penelitian ini di temukan pada 28 tulisan siswa yang telah dianalisis, sebanyak $75 \%$ siswa sudah tuntas dalam pembelajaran menulis permulaan dan 25 $\%$ siswa belum tuntas dalam menulis permulaan dikarenakan antara lain faktor kesulitan dalam motorik halus, kesulitan persepsi koordinasi visual motorik dan kesulitan visual memori dan kesulitan siswa dinilai dari aspek menulis permulaan yaitu: kesulitan siswa dalam susunan formasi, kerapian tulisan, spasi, ketepatan bentuk, proporsi dan kualitas garis tulisan.
\end{abstract}

Kata Kunci: Kesulitan Belajar; Menulis; Menulis Permulaan. 
Golden Age: Jurnal Pendidikan Anak Usia Dini, Volume 3 Nomor 2 (Desember 2019) ISSN 2549-8371 | E-ISSN 2580-5843

Ida Farida, Dayu Retno Puspita' Septy Nurfadhillah/Analyzing Writing Difficulties in The Beginning Writing of Second Grade Elementary School Students

\section{INTRODUCTION}

Education is necessary for every individual, be it among children, adolescents, adults, or elderly until when and wherever he is will be attached for life. One level of education that must be passed by students in elementary school education.

Learning in Elementary Schools is an activity to improve students' abilities. One of them is expected to have writing skills. Writing lessons include (1) writing by hand, (2) spelling, and (3) expressive writing (Lovitt, 1989). Writing by hand is also called beginning writing, and because writing is closely related to reading, reading and writing lessons in early elementary classes are often referred to as writing and beginning reading (Abdurrahman, 2012).

Based on Indonesian language subject competency standards in elementary school for writing learning materials, students are expected to be able to: write the beginning by tracing, thickening, copying, completing, copying upright letters through dictation activities, and copying through activities to complete stories and dictation, describing objects around and copying children's poetry (Asih, 2016).

Beginning writing is divided into two types: 1) Beginning Writing with Lowercase, Beginning writing using lowercase is taught in the first grade of elementary school. Beginning writing using lowercase letters is a process of imitating what is written by the teacher on the board and written by students. Writing a beginning is preferred to the introduction of letters through words and functional sentences; 2) Writing the beginning with capital letters in the initial letter of the beginning of the sentence, writing the beginning by introducing how to write capital letters or capital letters at the beginning of the sentence taught in the second grade of elementary school. In teaching writing this beginning, students are assigned to read over and over the reading. Then, they were assigned to rewrite sentence by sentence in their notebooks. Besides, students can also be assigned to retell the reading content by writing (Mukhlisah, 1993).

Beginning writing generally aims to provide students with the knowledge and skills to write well, starting from the initial level, namely from introducing sound symbols and the practice of holding stationery. As for the specific objectives 1) Copy simple language units; 2) write simple language units; 3) write simple statements and questions; 4) write short paragraphs (Iskandarwassid \& Sunendar, 2016; Subana \& Sunarti, 2000).

Based on the observations of one of the state elementary schools in Tangerang, the process of learning Indonesian, especially in the beginning writing, some students have not been able to write the beginning. Students have difficulty in writing correctly, the letters they write are not clear, students are slow in writing, writing letters or numbers with varying slope, writing out, down or up the line, writing in reverse letters, like $b$ is written $d$. Moreover, even there are still students who don't recognize letters.

From the above problems, students are suspected of having learning difficulties if the concern shows individual learning failures in achieving their learning goals.

Learning Difficulties, commonly referred to as Learning Disorder or Learning Difficulty, makes the individual concerned that it is difficult to carry out learning activities effectively. Factors that cause learning difficulties are not easy to determine because these factors are involved. These causative factors cannot be known but affect the brain's ability to receive and process information and the ability to learn specific fields of study that are suspected of having neurological resources that selectively interfere with the development, integration, and verbal and/or nonverbal abilities. (Abdurrahman, 2012; Jamaris, 2014; Ula, 2013).

Factors that cause learning difficulties can originate from 1) Internal Factors (Factors from within human beings themselves), which include Physiological Factors and Psychological Factors; 2) External factors (Factors from outside humans) include non-social factors and social factors (Ahmadi \& Supriyono, 2013).

Also, learning difficulties can be caused by damage to the central nervous system, biochemical imbalances, heredity, environmental factors, teratogenic effects (chemicals/drugs), injury to the brain due to physical trauma or due to lack of oxygen, food coloring substances, environmental pollution, inadequate nutrition, psychological and social effects which are detrimental to children's development (Abdurrahman, 2012; Jamaris, 2014).

Knowing the background of students' difficulties will make it easy for teachers to help overcome students' learning difficulties and provide an understanding that even though they have the same relative difficulties, they will have different backgrounds.

\section{RESEARCH METHODOLOGY}

The type of research method used descriptive qualitative. The purpose of this study is to describe systematically and factually the types and factors that cause difficulties in writing a beginning made by students at one of the elementary schools in Karang Tengah, Tangerang City. In this study, the data collection techniques 
Golden Age: Jurnal Pendidikan Anak Usia Dini, Volume 3 Nomor 2 (Desember 2019) ISSN 2549-8371 | E-ISSN 2580-5843

Ida Farida' Dayu Retno Puspita' Septy Nurfadhillah/Analyzing Writing Difficulties in The Beginning Writing of Second Grade Elementary School Students

used tests, interviews, observations, and documentation. The technique used in checking the data's validity was reducing data, presenting data, and drawing conclusions/verification.

\section{RESULT AND DISCUSSION}

\section{A. Result}

Data collection took three days. On the first day, the researcher submitted a research permit to the school to conduct research and explain the intent and purpose. On the second day, the researcher interviewed the teacher to explore student learning in the writing beginning of the class, the factors of difficulties experienced by students in the writing beginning, and the condition of the class during student learning.

On the third day, researchers came to class to give essay-shaped questions so that students rewrite the stories the teacher had read in their language and sentences each, after that student were asked to collect the results of their work on the teacher's desk, although most students easily collected, however, there are still some students who have not finished writing.

After the students' writing assignments are collected, the learning activities continue with questions and answers about the material that has not been understood and concluding activities followed by closing activities; then, the researchers collect data in the form of documentation of 28 students' writing.

Based on aspects that have been determined by researchers and class teachers of students' writing that has been known from the total number of students as many as 28 students, there are seven students classified as not having good writing skills or having difficulty in writing, 21 students are classified as having writing skills by fulfilling aspects of pre-determined aspects of the writing aspect.

The results of the research showed that students' writing learning started poorly. There were still many students who were not focused and severe in writing. Many student writing results are still not neat, many letters are reversed, although they have used the helpline there are still some students who write the same height, some write in the wrong lines, many student writings go up and down, the use of any capital letters is forgotten, and periods are often not used. Many students write words with fewer letters. Some students even shorten two words into one, so the written words are difficult to read. Some students initially write but eventually stop writing in the middle, so that only the first sentence is collected until the middle of the story.

\section{B. Discussion}

\section{The Difficulties of Students' beginning Writing}

There are some difficulties in learning to begin writing in students according to aspects of beginning writing.

a. Letter formation

This aspect assesses the ability of students in the arrangement of letters. In this aspect, students are asked to write the names of the letters.

\section{Picture 1. The Result from one of the students' writing in Letter Formation Aspect.}

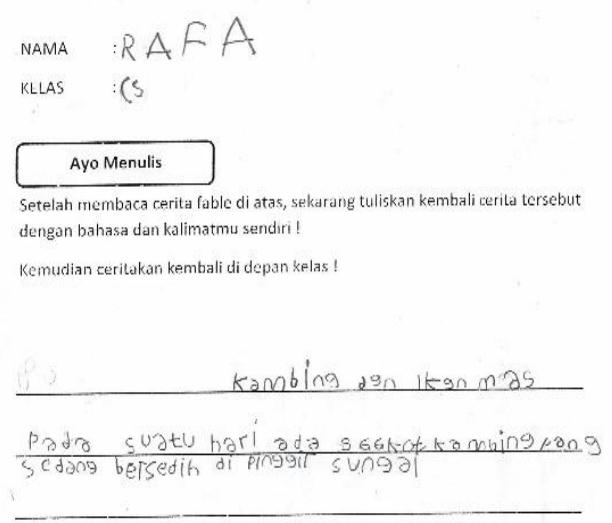

Testing obtained some students who have difficulty in this aspect, namely, AV, IMY, KS, MRNA, NNA, VA, and ZA. Because of the test results, they have not been able to finish their story until they finish writing only until the middle of the story, and some even write the first sentence of the story.

This is because 1) Difficult to express his ideas in writing; 2) Tend to have the concept of "floating" in writing; 3) Using unproductive strategies so that their vocabulary is limited. When they cannot find or spell a word correctly, they tend to replace it, so that it becomes uncommunicative; 4) Make mistakes often; 5) Requires more practice to achieve mastery of writing strategies (Graham \& Harris in (Marlina, 2019)).

\section{b. The neatness of the writing, the neatness of \\ The slope of the letters}

This aspect assesses the vertical quality of the manuscript, the slope of the cursive. This aspect assesses the neatness of the writing's clarity of writing, thorough, easy to read, and upright deep. 
Golden Age: Jurnal Pendidikan Anak Usia Dini, Volume 3 Nomor 2 (Desember 2019) ISSN 2549-8371 | E-ISSN 2580-5843

Ida Farida' Dayu Retno Puspita' Septy Nurfadhillah/Analyzing Writing Difficulties in The Beginning Writing of Second Grade Elementary School Students

\section{Figure 2. The Result from one of students' writing neatness aspect}

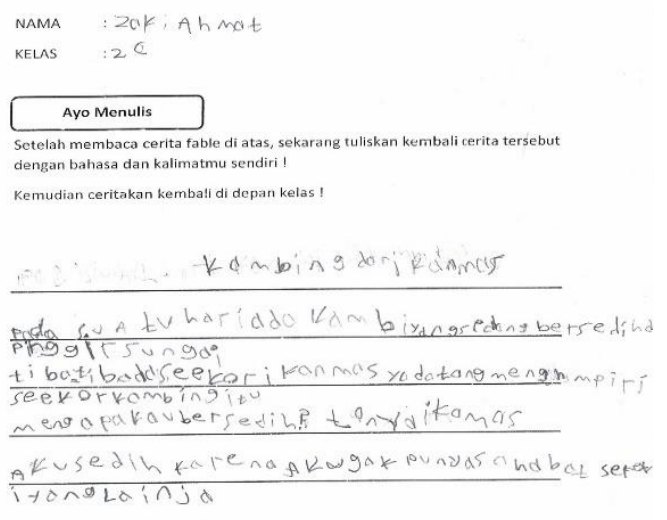

Based on the picture above, students are said to have difficulty in this aspect because there are still inconsistencies in the shape of letters in their writing, when writing uppercase and lowercase letters are still mixed, and the writing size is sometimes too large and sometimes too small, the writing is too thick or too thin. Students who have difficulty writing on this aspect, namely, AV, IMY, MRNA, NNA, VA, and ZA.

Difficulties in the fine motor (subtle motor problems) cause children not to write correctly because the letters they write are not clear, although children can spell letters well. Difficulties in this field cause child: 1) Slow in writing; 2) Writing letters or numbers with various slopes; 3 ) The writing is too thick because it is too pressed or too thin because of the hand pressure when writing is very little (Hildert in (Jamaris, 2014)).

\section{c. Space}

This aspect assesses the distance between letters and between words used as spacing and separating words, letters, numbers, or punctuation. Students are said to have difficulties in this aspect because, in writing, they do not use spaces/distances, the writing is too tight, and the spacing between letters is inconsistent-students who have difficulty writing on this aspect, namely, KS.

Several systems for categorizing handwriting errors have been proposed; for example, Wiederholt, Hammil, and Brown in (Marlina 2019) suggesting that teachers should examine the following essential points from children's manuscript writing: 1) Hand position; 2) Paper size; 3) Comparison or proportion; 4) The quality of pencil lines; 5) Slope; 6) Letter formation; 7) Straightness of letters; 8) Distance; 9) speed.

\section{d. Accuracy in Letter Form}

This aspect assesses the accuracy of the letters or numbers written by students, students are said to have difficulty in this aspect because, in writing, there are still inconsistencies in the form of letters in their writing, and there are still writing in reverse form; students who experience difficulties in this aspect namely, MRNA and ZA

\section{Picture 3. The Result from one of students' writing in letter form accuracy aspect}

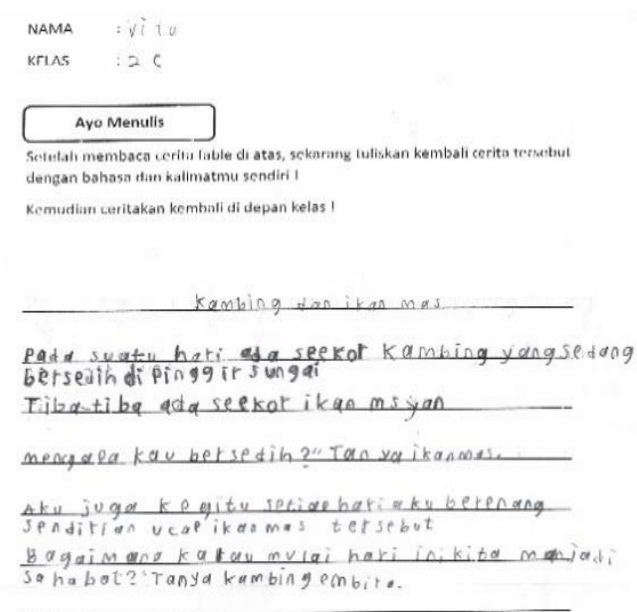

The inconsistency of the form of letters in writing is caused by the difficulty of visual-motor perception problems that cause children to have difficulty writing, such as 1 -writing out, down, or up the line. 2. Writing with the letters reversed, such as the letter $b$ wrote $d$, the letter $m$ written $w$, the number 6 is written 9 (Hildert in (Jamaris, 2014)).

\section{e. Proportion and Line Quality}

This aspect assesses the line quality of the pencil and the proportion of the writing-a comparison or proportion of one letter or word to another. Students are said to have difficulty because the way to write is not consistent and does not follow the proper and proportional line. Students who have difficulty writing on this aspect namely, AV, IMY, MRNA, VA, and ZA.

According to (Abdurrahman 2012), students who have difficulty learning to start writing can be seen by holding a pencil. There are four ways students hold a pencil that can be used as a clue that students have difficulty learning to write, namely: 1) The pencil angle is too large; 2) The pencil angle is too small; 3) Grasping a pencil (like punching); 4) Hold a pencil in your hand or drag.

\section{Factors That Cause Difficulty Students' Beginning Writing \\ Children who have learning difficulties} generally have difficulty writing. Hildert in (Jamaris, 
Golden Age: Jurnal Pendidikan Anak Usia Dini, Volume 3 Nomor 2 (Desember 2019) ISSN 2549-8371 | E-ISSN 2580-5843

Ida Farida' Dayu Retno Puspita' Septy Nurfadhillah/Analyzing Writing Difficulties in The Beginning Writing of Second Grade Elementary School Students

2014) suggests the factors that cause writing difficulties are as follows:

\section{1) Difficulty in fine motor skills}

Difficulties in fine motor skills cause children not to write correctly because the letters they write are not clear, although children can spell letters well. Difficulties in this field cause children: (1) slow in writing, (2) write letters or numbers with various slopes, (3) the writing is too thick because it is too pressed or too thin because the hand pressure when writing is very little. Students who experience difficulties in this field are AV, IMY, MRNA, NNA, VA, and $Z A$.

Lerner also reinforces this opinion in Abdurrahman (2012) several factors affect a child's ability to write, (1) motor, (2) behavior, (3) perception, (4) memory, (5) ability to carry out crossmodal, (6) the use of a dominant hand, (7) the ability to understand instructions. Children whose motor development is immature or impaired will experience difficulty writing; the writing is unclear, disjointed, or does not follow the line.

\section{1) Difficult Perceptions of Visual-Motor Coordination}

Difficulties in the visual-motor field cause children to have difficulty in writing, such as (1) writing out, down, or up the line, (2) writing in reverse letters, such as letter $b$ wrote $d$, and letter $\mathrm{m}$ wrote $\mathrm{w}$, number 6 written 9 . Students who have difficulty in this field, namely: AV, IMY, MRNA, VA, and ZA.

Several factors affect the child's ability to write one of them is perception; children whose perception is disturbed can cause difficulties in writing. If the visual perception is disrupted, the child may find it challenging to distinguish letter shapes almost the same as $d$ with $b, p$ with $q, h$ with $n$, or $m$ with $w$. if the auditor's perception is disturbed, maybe the child will have difficulty writing words spoken by the teacher (Abdurrahman, 2012).

\section{1) Visual Memory Difficulties}

Difficulties in the visual field of memory make it difficult for children to remember the shape of the letters that will be written material. This causes the child to be slow in doing handwriting activities. Students who experience difficulties in this field are MRNA and ZA.

The factors that affect students' ability to write are memory; memory disorders can also be a cause of learning difficulties to write because children cannot remember what will be written. If the disorder involves visual memory, then the child will find it difficult to remember letters and words; and if the disorder involves auditory memory, children will have difficulty writing words that have just been spoken by the teacher (Abdurrahman, 2012).

\section{CONCLUSION AND SUGGESTION}

\section{A. Conclusion}

Based on the description and interpretation of data, it can be concluded:

1. Based on the results of tests conducted with a total of 28 students, only seven students who had difficulty writing the beginning indicated by low scores on almost all aspects of writing while the rest had difficulty writing on certain aspects (7 students had difficulty in aspects of letter formation, six students experienced difficulties in the aspect of the neatness of writing, one student had difficulty in the aspect of spacing, two students who had difficulty in aspects of the accuracy of the form of letters and five students had difficulty in aspects of the proportion and quality of written lines).

2. Factors that cause difficulties in beginning writing to students are 1) Difficulties in Fine Motor (6 students who experience difficulties in this field); 2) Difficulties Perception of Visual-Motor Coordination (5 students who experience difficulties in this field); 3) Visual Memory Difficulties (2 students who experience difficulties in this field). Moreover, 21 students were declared complete and already had the initial writing skills by the expected aspects and competencies.

\section{B. Suggestion}

There are several suggestions proposed by the author: 1) For teachers to emphasize again how to write a good start and correct and pay more attention to the level of difficulty of students in writing the beginning; 2) For students to multiply writing exercises to improve their writing skills; 3) Environmental settings that can provide benefits in improving children's learning outcomes and development.

\section{REFERENCES}

Abdurrahman, M. (2012). Anak Berkesulitan Belajar. Jakarta: Rineka Cipta.

Ahmadi, A., \& Supriyono, W. (2013). Psikologi Belajar. Jakarta: Rineka Cipta.

Asih. (2016). Strategi Pembelajaran Bahasa Indonesia. Bandung: CV Pustaka Setia. 
Golden Age: Jurnal Pendidikan Anak Usia Dini, Volume 3 Nomor 2 (Desember 2019)

ISSN 2549-8371 | E-ISSN 2580-5843

Ida Farida' Dayu Retno Puspita' Septy Nurfadhillah/Analyzing Writing Difficulties in The Beginning Writing of Second Grade

Elementary School Students

Iskandarwassid, \& Sunendar, D. (2016). Strategi Pembelajaran Bahasa. Bandung: Remaja Rosda Karya.

Jamaris, M. (2014). Kesulitan Belajar Perspektif, Asesmen, dan Penanggulangannya. Bogor: Ghalia Indonesia.

Lovitt, T. C. (1989). Introduction to Learning Disabilities. Boston: Allyn and Baron.

Marlina. (2019). Asesmen Kesulitan Belajar. Jakarta: Kencana Prenadamedia Group.

Mukhlisah. (1993). Pendidikan Bahasa Indonesia 3. Jakarta: Penerbit Universitas Terbuka.

Subana, \& Sunarti. (2000). Strategi Belajar Mengajar Bahasa Indonesia. Bandung: Pustaka Setia.

Ula, S. (2013). Revolusi: Belajar Optimalisasi Kecerdasan melalui Pembelajaran Berbasis Kecerdasan Majemuk. Yogyakarta: Ar-Ruzz Media. 